most of the increases in the allocations for R\&D in the Arab world have taken place in oil producing countries; elsewhere, little increase in funding is recorded.

The Arab scientific communities, the educational systems, their immediate environments, their relationships to the users of technology, and the resources of the Arab states have all been undergoing far-reaching changes. It is very difficult at this moment to identify clearly the new directions that are emerging. On the surface, it would seem that the traditions of the past three decades are firmly entrenched. This can be seen from the CASTARAB 1976 meeting in Rabat, the 1978 Kuwait Fund for Arab Economic Development feasibility study on the proposed Arab Fund for Scientific and Technological Development, as well as the national papers submitted to UNCSTD. Nevertheless a large number of indicators point to the possibility of major departures. Since the early fifties, the production of scientific and technical manpower has been expanding at an exponential rate, with a doubling time of about 5.3 years. If this rate continues, the one million university graduates of 1978 would have grown to more than 12 million by the year 2000 . The 24,000 foreign trained doctorate holders could reach a level of $150,000-250,000$ by the year 2000 .

Meanwhile, the capacity of the US and Europe to drain unwanted high level manpower has been reduced by the economic recession registered there. Furthermore, the size of Arab technical manpower is rapidly reaching a level that makes likely drains an insignificant portion of the total pool of educated manpower. The absorption of this enormous manpower cannot be achieved without effecting major structural changes in current practices of planning and executing development projects. All Arab countries are undergoing rapid social and economic change. Ministries, institutions, industrial installations, and transport systems are all being developed at a high rate. But many developmental projects are being executed in a manner that does not utilise existing technical skills or institutions. This leads to a low level of employment generation within the Arab countries themselves. An interesting comparison provides an indication of the extent of this fact: Imperial Chemical Industries (ICI) provides direct and indirect employment in the UK comparable to that of the hydrocarbon sector in the Arab world; but the sales of Arab oil are roughly ten times those of ICI. Obviously the only way in which the five million graduates in the applied and basic sciences are going to find employment is if the present technological dependence is reduced through the use of indigenous firms and institutions. Technology policies will certainly assume increasing social and political importance during the next two decades. The very stability of Arab countries will depend on

\section{Mountains out of molehills}

ONE of the less attractive habits of our species, Homo sapiens (sic), is the way in which we attribute our unpleasant behaviour patterns to other animals. Thus the human glutton is described as a pig or a hog, and the term swine is used to cover a multitude of our sins. Male chauvinists are pigs, and their women bitches when they assert their rights, cows when they do not, and cats when they criticise other women. Occasionally diminutives like kitten are used more affectionately, but as a rule the comparison with an animal is a derogatory one.

1979 has been called 'The Year of the Mole' - with the mole cast as the villain of the piece. Thus while the majority of viewers could not make head or tail of the BBC television serial Tinker, Tailor, Soldier, Spy, they did understand that there was a traitor high up in the security organisation who was passing vital information to the enemy - in other words, a 'mole'. This programme had hardly left our screens when we had the real life case of Anthony Blunt, a distinguished art historian and advisor on pictures to the Queen, who confessed to having been a Communist agent passing information to the Russians when he was attached to the British secret service. $\mathrm{He}$ was the mole par excellence. Then for some years British Leyland, the ailing motor manufacturer, has had its troubles exacerbated by the actions of a Communist shop steward, commonly called the 'red mole'.

Yet the furry little insectivore Talpa europaea, has little in common with a spy or a disruptive agitator. It must be admitted that it is equally unlike the loveable and friendly animal featured in Kenneth Grahame's delightful children's book The Wind in the Willows, and presented so vividly on stage in London each Christmas by the redoubtable octogenarian actor Mr Richard Goolden in the play Toad of Toad Hall. Moles do indeed live underground in burrows, but their most striking characteristic is their solitariness. Rudyard Kipling wrote, in this case with reasonable accuracy, about 'The Cat which Walked Alone', but the mole is very much more independent than

the development of employmentgenerating technology policies.

A profound religious and ethical rejection of the stark contrast between wealth and poverty pervades the Arab world. This has so far led to the establishment of a number of Arab funds (national and regional) that aim to assist sister countries in their development. Finally, the difficulties and mechanics of development are becoming clearer, the

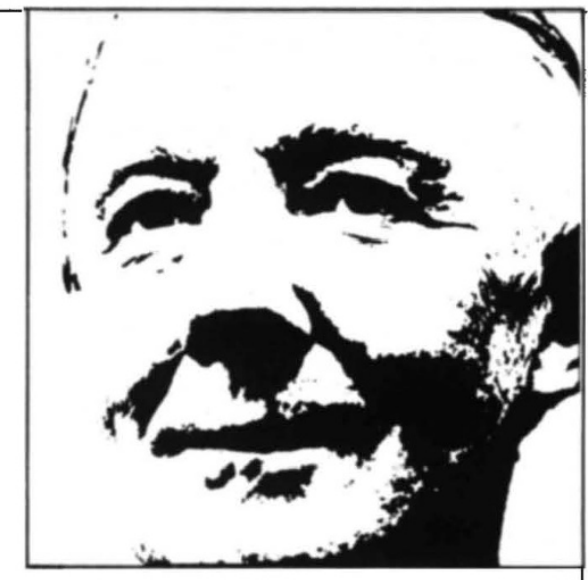

\section{KENNETH MELLANBY}

the most self-centred domestic pussy.

In fact it is difficult to see anything in the life history of the mole in common with that of a spy. For almost the whole of their lives, both males and females occupy their own separate sections of underground tunnell, and spend the time in sleep or in running up and down picking up worms and insects which have dropped into the burrow. Should a mole be foolish enough to invade another's territory, it is usually driven off at once. Except for a brief period once a year when the female accepts the attentions of the male, when mole meets mole there is at once open hostility and even bloody combat. There is nothing subtle, deceitful or underhand in the behaviour of Talpa.

Gardeners who suffer from the appearance of molehills on their carefully manicured lawns may perhaps be excused for saying nasty things about the culprit, but at least they must admit that by making its presence so noticeable the burrower is hardly being secretive or underhand. So should we not try to find some other zoological sobriquet for a traitor or an industrial troublemaker? I fear that any suggestions will arise the wrath of some other mammalologist involved with the libelled species.

Finally, I find that I am, unwittingly, involved in an attempt to cash in on the current interest in moles. I read in the London newspaper The Financial Times that: "Collins the publishers tell me that they have had some discussions about expanding the title of Professor Kenneth Mellanby's book The Mole to The Mole - the Blunt Truth".

social and political cost of inaction is growing increasingly evident, the enormous resources of the Arab world are gradually coming under the control of local institutions and governments. What, when and how a zipper action will operate to cohere all of these disjointed resources is difficult to forecast. But when it does happen the scientific communities of the Arab world will be called on to play a leading role. 